\title{
ONLINE ENGLISH LEARNING: MAIN PROBLEMS AND SOME WAYS TO SOLVE THEM
}

\section{(C) A.L. Kuregyan, E.A. Pertsevaya}

Samara State Technical University, Samara, Russian Federation Samara State Economic University, Samara, Russian Federation

- For citation: Kuregyan A.L., Pertsevaya E.A. Sonline english learning: main problems and some ways to solve them. Vestnik of Samara State Technical University. 2021;18(1):47-56. https://doi.org/10.17673/vsgtu-pps.2021.1.4

Nowadays distance learning (DL) has become a universal way of teaching students both technical and humanitarian disciplines. Any foreign language requires the mastering of a large number of teaching materials, this number increasing due to the language skills heterogeneity in each group and this requires the development of specific skills in each individual group of students. Hence, learning priorities must be correctly prioritized and the specific area of knowledge must be presented in details. This paper focuses on the main problems of the $\mathrm{DL}$ and some ways to overcome them. To observe the topic under consideration, research philosophy was chosen as a core method of scientific investigation. Comparative and qualitative analysis were used to understand and interpret definitions applied in the paper. In the process of DL, the authors have identified aspects that need to be taken into account when providing tasks for different levels groups. In this regard, reference is also made to the tasks and exercises that have proved to be very effective during the DL interaction with students.

Keywords: DL, distance learning, on-line learning, class materials, English teaching, educational environment, listening, reading, speaking, writing.

\section{ОНЛАЙН ОБУЧЕНИЕ АНГЛИЙСКОМУ ЯЗЫКУ: ПРОБЛЕМЫ И СПОСОБЫ ИХ РЕШЕНИЯ}

\author{
(С) А.Л. Кюрегян, Е.А. Периевая \\ ${ }^{1}$ Самарский государственный технический университет, Самара, Россия \\ ${ }^{2}$ Самарский государственный экономический университет, Самара, Россия \\ Поступила в редакцию 09.12.2020 \\ В окончательном варианте 11.02.2021
}

- Аля цитирования: Кюрегян А.А., Перцевая Е.А. Онлайн обучение английскому языку: проблемы и способы их решения // Вестник Самарского Государственного Технического Университета. 2021. Т. 18. № 1. С. 47-56. DOl: https://doi.org/10.17673/vsgtu-pps.2021.1.4

\footnotetext{
Дистанционное образование в 2020 году стало повсеместным и универсальным способом обучения студентов всем дисциплинам, как технической, так и гуманитарной направленности. Иностранный язык предполагает освоение большого количества учебных материалов, количество которых увеличивается вследствие неоднородности уровня владения языком в каждой группе, что требует отработки конкретных умений в каждой
} 
отдельно взятой группе студентов. Соответственно, необходимо правильно расставить приоритеты при обучении и максимально детально представить для изучения конкретную область знаний. В статье рассматриваются основные проблемы перехода на дистанционную форму обучения иностранным языкам и некоторые советы по их преодолению. При переходе на дистанционное обучение, авторами были выявлены аспекты, которые необходимо учитывать, предоставляя задания группам разных уровней. В этой связи, также упоминаются варианты заданий, которые оказались весьма эффективными в практике перехода на дистанционный вариант взаимодействия со студентами.

Ключевые слова: дистанционное обучение, онлайн обучение, материалы для проведения занятий, обучение английскому языку, образовательная среда, аудирование, чтение, говорение, письмо.

\section{Introduction}

Transformations taking place in our society during XX-XXI centuries actively affect the development of technological processes, and as a result, also influence the introduction of the technological changes results in the education system. The need of modern society for competitive and highly qualified specialists capable of working with large volumes of information has been reflected in a new teaching approach, i.e. it has become possible to use some tasks in a distance form.

DL has traditionally been considered a priority for students studying technical disciplines and it was explained with the help of several practical aspects. The first aspect was due to the difficulties encountered in trying to formalize teaching materials in the humanities disciplines, while the second aspect was due to the fact that technical school personnel were more competent in using new information technologies and software [1]. As it was stated above, humanitarian education made only the first attempts to use DL technologies.

The problem of finding the effective tools and tasks to ensure the high-quality language education in the process of rapid transition to DL technologies is considered in the article. The problem solutions of not having enough electronic material in the process of teaching are offered, based on the personal experience of the authors, gained while working in two higher educational establishments in Samara.

\section{Literature review}

Nowadays DL is widely discussed in Russian and foreign literature.

Traditionally, DL was considered as the possible way of integration with the traditional learning scheme [1]. This method had all the drawbacks that prevented its introduction in the past: students and professors not being ready to apply the new technologies, not having enough courses and not taking into consideration the conditions of effective introduction of DL techniques into teaching practice [2].

DL is a synthetic, integral humanistic form of learning based on the use of a wide range of traditional and new information technologies and their technical means, which are used to deliver educational material, its independent study, and a dialogue between a teacher and a student [3].

$\mathrm{DL}$ is a form of learning in which interaction between a teacher and students is carried out at a distance and reflects all the inherent components of the learning process (goals, content, methods, organizational forms, learning tools) implemented by specific means of Internet technologies or other means that provide interactivity» [4]. 
Scientists from Moscow State University of Economics, Statistics, and Informatics consider DL to be a technology of learning at a distance, when a teacher and a student are physically located in different places. Previously, DL meant DL. Now it is a means of learning that uses case, TV and network learning technologies» [5].

A.V. Khutorskoy, E.S. Palat suppose that DL is a process by means of telecommunication where students, teachers, tutors, etc having spatial or temporal remoteness, carry out a common learning process aimed at creation of external educational products and corresponding internal changes (increments) of educational subjects» [6].

We are going to base our research on the DL as a form of education that is built according to the same objectives as full-time education $[3,4,7]$. But the form of material presentation is different.

DL (regarded as a «mechanism» for optimizing vocational education, characterized by a transition from a reproductively passive to a productive and active paradigm of knowledge acquisition, to education based on interactive and constructive activities of a learner and a teacher (subject-to-subject relations) [8]) was introduced without any preparation, leaving the teachers and professors of different subjects with a very limited number of teaching tools and techniques to cope with this change.

In the context of the transition to DL, the active attitude of teachers [9] has become particularly important, as they were to provide students with all the necessary amount of material and tasks as quickly as possible. The submission form is determined by the specific features of DL and the possibilities of the information environment, including the Internet [10].

Techniques to improve learning effectiveness in virtual learning environment seek to find relationships connections between pedagogical advances and educational technological resources available [11]. Some of those environments were introduced by Samara higher educational institutions.

It is worth mentioning that DL has several essential features, including the environment of interaction, means, materials used, knowledge control and general evaluation [12]. Most of those features proved to be relevant and most problematic in the transition to online English teaching.

\section{Materials and methods}

The research process was made by the authors during the work process while they were teaching the aspects of the English language (business communication, written translation, general language etc.) at Samara State Technical University and Samara State University of Economics. The rapid transition to DL practices which happened in March 2020 due to quarantine measures introduced by different states, provoked the introduction of online teaching technologies in all areas of education, so the period of research in our article should be limited by 7 months of observation and active participation in the process of DL (3 months during the spring semester and 4 months in the fall semester).

Thus, the authors of the article identified and grouped some of the most common and up-to-date problems, concerning the rapid transition to DL according to their working experience in the Samara State Technical University and the Samara 
State University of Economics. In spring 2020 those problems were the following ones:

1. A great variety of programmes and teaching tools offered to the teacher free of charge and on the commercial basis (for example: Skype, Zoom, Big Blue Button);

2. An extremely wide range of materials allowing to teach different language aspects: grammar, vocabulary, pronunciation, etc.;

3. The need to create a whole course aimed taking into account all the listeners of every particular group studying a foreign language at the university;

4. Obtaining reports on the task performance;

5. Evaluation of the knowledge received.

Table 1

Comparison of online and offline teaching.

\begin{tabular}{|l|l|l|}
\hline \multicolumn{1}{|c|}{ Aspect } & \multicolumn{1}{|c|}{ Traditional offline teaching } & \multicolumn{1}{c|}{ Distance online teaching } \\
\hline Environment of interaction & In class, face-to-face & Numerous platforms \\
\hline Means and materials & Limited by the textbook & $\begin{array}{l}\text { Unlimited, existing in } \\
\text { various forms }\end{array}$ \\
\hline Structured course & Existing & Non-existing \\
\hline Everyday control & In class & Distant \\
\hline General assessment & $\begin{array}{l}\text { Precise, based on the task } \\
\text { completion in class and homework }\end{array}$ & $\begin{array}{l}\text { Non precise, based on } \\
\text { the tasks completion only }\end{array}$ \\
\hline
\end{tabular}

The five important aspects of online in comparison with offline education are considered in the article together with offering the task that in the authors' opinion, suits all those aspects best.

To observe the topic under consideration, research philosophy was chosen as a core method of scientific investigation. It is an important basis of every research, no matter what scientific field the paper is referred to. Also, with the help of research philosophy method, it was decided to use data collection which has been done by the authors while working. Comparative and qualitative analysis were used to understand and interpret definitions applied in the paper.

The research methodology is also based on the thorough analysis of the scientific research results of leading Russian and foreign scientists. It reflects modern approaches in the field of facilitative education applied to the online format existed.

\section{Research results}

The fast transition from the traditional offline education to DL, happened in spring 2020, revealed some of the problems of online education practices from the point of view of the English language teachers and professors as well as the students in Russia.

Compared to the traditional offline teaching, the existing online distance format has several features.

With regard to a large number of options of virtual learning environment the teacher must take into account some specific features of DL. For example, when broadcasting the image, the choice of the most popular programmes is determined by the number of students in a group. If the number of students is expected to be 
small, it is more appropriate to use Skype, if the number of participants is expected to be large to use Zoom, BBB conference mode is more preferable.

If communication is supposed to be mainly written, it is reasonable to use various educational platforms that exist in educational institutions and represent an electronic DL environment.

When working directly with an audience, the teacher has all the necessary teaching materials at his/her disposal and is also able to share his/her knowledge with students. When introducing DL, it is necessary to lay out the training material with a variety of tasks in a very short period of time for students to have an opportunity to look it through.

It is not a problem when using authentic sets of materials, which are presented practically in all the textbooks of well-known publishing houses, but not all groups use such courses, and the conditions of DL make it necessary to react to such changes of the usual offline educational practices very quickly.

Variety of learning materials is also considered to be a problem of choice in DL. The teacher has a number of different resources for listening to select, but it is worth using only proven sources to find the material under tight deadlines of an extremely fast transition from the traditional face-to-face teaching to DL introduced in spring 2020. Such sources are usually based on long-established news or entertainment channels. All these channels must be authentic, i.e. those that present the correct use of words or the subject. In our article, all the sources listed are in English.

The problem of creation the whole new structured online course remains one of the most serious and utmost. When transitioning to DL of any foreign language every teacher should have a ready developed e-learning course. The creation of such courses requires a fairly long period of time as it is group-oriented. This process eliminates gaps in grammar, vocabulary and word compatibility. In some cases, problems arise even with the basic rules of reading and the fundamental inability to use the established English language norms. In this case, a large amount of additional material is required in various areas of foreign language knowledge: for example, correct names of geographical objects, reading certain combinations of letters, translation of lexical units similar to Russian ones, etc. Hence, it is necessary to develop assignments for English DL in higher educational institutions.

The problem with the immediate transition to DL is everyday control. This aspect is fully accounted for the students' self-discipline and consciousness, since at the early beginning of DL it was supposed that only an oral statement and a written document can be subjected to an immediate checking in the conditions of having 15 or more students in the group of learners (and having 3 or 4 classes with a minimal interval between them). Of course, the photo of a text with a handwritten task remains as a feedback option, but it implies an extremely quick response from the teacher to the correction made to the text. The student must then quickly change what is written and show it to the teacher. In general, it is more convenient for the work to use the Word text editor.

The assessment problem is an additional source of difficulties, but the text written independently does not present any. It must be remembered that the topic should be unique to each group. Interesting topics are those based on the answers that students give during the class when discussing a problem, so such aspects should be considered and remembered. 
Of course, the rapid development of DL technologies will make it possible in the future to identify the most convenient types of work, taking into account the transmission of images and sound, but currently it is necessary to focus on the gradual new technologies mastering.

Thus, during the transition to DL, while working with students, having different levels of English in higher educational institutions of Samara, the authors have identified the following aspects that need to be taken into account when providing tasks for different levels groups in order to minimize the problems mentioned above.

Also, when selecting a task, a DL teacher should consider several aspects which are rather important in comparison with traditional offline process speed, attachment and feedback.

The first aspect is the speed given to conduct each specific task (the difficulty level is variable, but it must correspond to students' knowledge). In on-line interaction, the speed of the work is very difficult to predict, because the tasks that seem simple to the teacher are quite time consuming for students.

The second aspect is maximum attachment of the assignment to the material being studied. Since all the assignments and their answers are given in real time at short response intervals, it is necessary to maintain students interest in the topic being studied by means of various assignments.

The third aspect is the ease of providing feedback and specific questions that need to be answered orally or in writing. When setting the task, it is essential to pay attention to the length of the answer in minutes when the task is oral and in the number of sentences or words if it is a written one.

In this regard, mention should be made to the tasks that proved to be very effective when transitioning to DL.

So, the materials should be divided into the main speech activities (listening, reading, speaking, writing) and we should try to pay attention to each of them during the lesson. Due to the difficulties in organizing distance communication even with the most self-disciplined students, it is not always feasible in practice, but when planning a lesson, all possible tasks variants should be thought over in advance.

The simplest task concerns the listening aspect, since here we can use the entire volume of materials posted on multimedia channels.

For example, the possible task might be "Watch the Video". While introducing the task for the first time, the teacher can check the level of difficulty, the speed of completion and material for possible feedback and then adapt them to the abilities and needs of a particular group of students. In comparison with an audio clip, video provides an additional visual range, so it is more preferable while working. In DL the ways of information perception also change, the number of influence methods is reduced, which makes it necessary to improve the impact quality and intensity of presenting information. For example, the role of infographics in training increases, and the quality requirements for its creation also rise [12, p. 80-81; 7; 8, p. 21-23].

Currently, there is a huge number of resources providing the opportunity to use the videos and on-line lectures, but for educational purposes you should use only checked resources (for example, the website about learning English broadcasting Corporation BBC [13] or the British Council [14], and lectures by famous scientists on the portal TED Talks [15]). It is best to use an extract of at least 5 and no more 
than 10 minutes. You should pay special attention to the fact that DL requires more tasks aimed at entertaining the audience.

As a pre-viewing task to the video, you can use the following assignment - the teacher writes out the words and phrases used in the video in advance, and students are given a list of these words in the form of a table to be translated. Students can be asked to use these lexical units in their own story, and repeat them in the next lesson by translating the sentences indicated by the teacher (a written version of speech activity).

The video is also associated with the task "Answer the following questions". Moreover, the higher the level of language used in the video, the more likely the task will take much more time to be completed than the teacher might have expected at the beginning.

The reading aspect is also quite simple for selecting material. A large number of texts provided for free reading by English-language newspapers allows you to choose an interesting text related to current issues.

Since Russian is the native language for most students, you should also include the aspect of translation from English into Russian, because otherwise the vocabulary is difficult to remember, and place special emphasis on this newly studied vocabulary.

A very effective version of written text translation is the one that contains combinations developed in the video, and the translation can be performed from English into Russian, or vice versa. When using a translation from English, one of the most effective tasks is to create a dictionary of the lexical units used in the text. You can limit students to the number of words - for example, 15-and ask them to exchange dictionaries in order to test their translation skills. If the teacher receives all versions of dictionaries in written form, then he/she forms a certain bank of words that can be used in further work with dictionary units of this kind.

Final task when watching a video is a response to the question related to the topic of the video, which can be made in written form (in this case, the students send their work to a teacher), or in the format in which the response is read out and recorded, and a teacher listens to the recorded student oral speech, which is also a kind of speaking aspect test.

\section{Discussion}

Any foreign language mastering requires studying a large number of materials, this number is constantly increasing. Hence, learning priorities must be correctly prioritized and the specific area of knowledge must be presented in details. DL as a form of education is a very promising method to be integrated with the traditional offline education [16].

In our practice, we often faced the fact that a fully planned lesson took a completely different development direction: for example, when discussing variants for spending free time, the gerund turned out to be an absolutely unknown grammatical phenomenon for students, so we had to change the structure of the lesson in real time and carefully study the grammar necessary for successful completion of tasks. Such a change is easily possible when the teacher works directly with the audience, but considerable time and effort is required when searching for materials on-line.

It should be noted that when teaching a foreign language the work to create any e-learning course is particularly time-consuming, since it is necessary not 
only to schedule the main tasks for each language level and provide the necessary materials, but also to prepare a significant amount of materials designed for all kinds of deviations. Such work is more effective if you accumulate a large number of multimedia materials and tasks related to the most frequently repeated mistakes made by students when learning any foreign language.

The results presented in the article solve several problems mentioned above. Such a quick transition showed the necessity of having a lot of tasks ready to be shared with students, and watching the video task is just the quick solution of this problem. The idea of restructuring the existing tasks used in the process of teaching English was very popular during the isolation period and the future perspectives of the study could be seen as the further development of the techniques and methods of DL that could easily be implemented and in a short period of time and be effective in English DL.

\section{REFERENCES}

1. Valeeva R.Z., Valeev E.R. Distantsionnoe obuchenie kak faktor povysheniya kachestva obrazovaniya $\mathrm{v}$ sisteme vysshego professional'nogo obrazovaniya [DL as a factor of education quality improvement in the system of higher professional education] // Vestnik Kazanskogo gosudarstvennogo universiteta kul'tury i iskusstv. 2013. № 4-2, pp. 75-79.

2. Andreev A.A. K voprosu ob opredelenii ponjatija «distantsionnoe obuchenie» [On the definition of the Distance Learning notion]. URL: http://www.e-joe.ru/sod/97/4_97/st096.html (accessed 05.11.2020).

3. Popova N.E., Chikova O.A. Tekhnologii distantsionnogo obucheniya kak innovatsiya $\mathrm{v}$ protsesse realizatsii obrazovatel'nyh standarov novogo pokoleniya. [Technologies of DL as innovation in the process of new generation educational standards realization] // NSPU Bulletin. 2014. №2 (18), pp. 17-24.

4. Polat E.S., Buharkina M.Ju., Moiseeva M.V. Teorija i praktika distantsionnogo obuchenija [Theory and practice of distance learning]: Ucheb. posobie dlya studentov vysshyh pedagogicheskih uchebnyh zavedenij / Pod red. E.S. Polat. M.: Izdatel'skij centr «Akademija», 2004.

5. Moskovskij gosudarstvennyj universitet ekonomiki, statistiki i informatiki Otkrytoe obrazovanie. Terminy i opredelenija [Moscow State University of Economics, Statistics and Informatics Open Education. Terms and definitions]. URL: http://www.info.mesi.ru/program/ glossaryOO.html (accessed 03.12.2020).

6. Polat E.S., Hutorskoj A.V. Problemy i perspektivy distantsionnogo obrazovanija v srednej obrazovatel'noj shkole [Problems and Prospects of Distance Education in Secondary School]. URL: http://www.ioso.ru/ioso/senatus/ meeting280900.htm (accessed 12.10.2020).

7. Sharov V.S. Distantsionnoe obuchenie: forma, tehnologija, sredstvo // Pedagogika. [Distant learning: form, technology, means]. URL: https://lib.herzen.spb.ru/text/sharov_94_236_240. pdf (accessed 13.10.2020)

8. Roberto D. Costa, Gustavo F. Souza, Ricardo A.M. Valentim, Thales B. Castro. The theory of learning styles applied to DL / Cognitive Systems Research, Volume 64, 2020, pp. 134145. URL: http://www.sciencedirect.com/science/article/pii/S1389041720300504 (accessed 01.12.20)

9. Bikkulova G.R. Metodika distantsionnogo formirovaniya kommunikativnoj kompetentsii studentov estestvennyh fakul'tetov universiteta: na materiale anglijskogo yazyka. [Method of communicative competence distance formation of students studying natural sciences at the university: based on the English language]. URL: https://www.dissercat.com/content/metodika-distantsionnogo-formirovaniya-kommunikativnoi-kompetentsii-studentov-estestvennykh(accessed 01.12. 20) 
10. Burenina S.V. Prepodavanie anglijskogo yazyka dlya professional'nyh tselej: metodicheskie i organizatsionnye problemy [Teaching English for Professional Purposes: Methodological and Organizational Problems] // Vestnik Samarskogo gosudarstvennogo tekhnicheskogo universiteta. Seriya: Psihologo-pedagogicheskie nauki. 2019. № 3 (43), pp. 19-30.

11. Loseva E.S., Gozalova M.R., Makarova A.I. Problemy distantsionnogo obucheniya inostrannym yazykam na stupeni vysshego obrazovaniya [Problems of distance learning of foreign languages on the level of higher education]. URL: https:// www.elibrary.ru/item.asp?id=41122260 (accessed 01.12.20)

12. Marchuk N.Yu. Psihologo-pedagogicheskie osobennosti distancionnogo obucheniya // Pedagogicheskoe obrazovanie v Rossii. [Psychological and pedagogical features of DL] // Pedagogical education in Russia. 2013. №4, pp. 78-85.

13. Learning English - BBC. https://learnenglish.britishcouncil.org/ (accessed 01.12.20).

14. Learn English Online | British Council. https://learnenglish.britishcouncil.org/ (accessed 01.12.20).

15. TED Talks. https://www.ted.com/ (accessed 01.12.20)

16. Gerashchenko I.G., Gerashchenko. N.V. Problemy distantsionnogo obrazovaniya: metodologicheskij aspekt. [Problems of distance learning: methodological aspect]. URL: https://cyberleninka.ru/article/n/problemy-distantsionnogo-obrazovaniya-metodologicheskiyaspekt (accessed 01.12.20).

\section{СПИСОК АИТЕРАТУРЫ}

1. Валеева Р.3., Валеев Э.Р. Дистанционное обучение как фактор повышения качества образования в системе высшего профессионального образования//Вестник Казанского государственного университета культуры и искусств. - 2013. - № 4-2. - С. 75-79.

2. Андреев А.А. К вопросу об определении понятия «дистанционное обучение» [Электронный pecypc]. URL: http://www.e-joe.ru/sod/97/4_97/st096.html (дата обращения 05.11.2020).

3. Попова Н.E., Чикова О.А. Технологии дистанционного обучения как инновация в процессе реализации образовательных стандартов нового поколения // Вестник НГПУ. - 2014. - № 2 (18). - С. 17-24.

4. Полат Е.С., Бухаркина М.Ю., Моисеева М.В. Теория и практика дистанционного обучения: Учеб. пособие для студентов высших педагогических учебных заведений / Под ред. Е.С. Полат. М.: Издательский центр «Академия», 2004.

5. Московский государственный университет экономики, статистики и информатики Открытое образование. Термины и определения [Электронный pecypc]. URL: http:// www.info.mesi.ru/program/ glossaryOO.html (дата обращения 03.11.2020).

6. Полат Е.С. Хуторской А.В. Проблемы и перспективы дистанционного образования в средней образовательной школе: Доклад [Электронный pecypc]. URL: http://www.ioso. ru/ioso/senatus/ meeting280900.htm (дата обращения 12.10.2020).

7. Шаров В.С. Дистанционное обучение: форма, технология, средство // Педагогика. [Электронный ресурc]. URL: https://lib.herzen.spb.ru/text/sharov_94_236_240.pdf (дата обращения 13.10.2020)

8. Roberto D. Costa, Gustavo F. Souza, Ricardo A.M. Valentim, Thales B. Castro. The theory of learning styles applied to DL / Cognitive Systems Research, Volume 64, 2020, pp. 134-145. URL: http:// www.sciencedirect.com/science/article/pii/S1389041720300504 (accessed December 1, 2020)

9. Биккулова Г.Р. Методика дистанционного формирования коммуникативной компетенции студентов естественных факультетов университета: на материале английского языка [Электронный ресурc]. URL: https://www.dissercat.com/content/metodika-distantsionnogoformirovaniya-kommunikativnoi-kompetentsii-studentov-estestvennykh- (дата обращения 04.10.2020). 
10. Буренина С.В. Преподавание английского языка для профессиональных целей: методические и организационные проблемы// Вестник Самарского государственного технического университета. Серия: Психолого-педагогические науки. - 2019. № 3(43). - C. 19-30.

11. Лосева Е.С., Гозалова М.Р., Макарова А.И. Проблемы дистанционного обучения иностранным языкам на ступени высшего образования [Электронный ресурс]. URL: https://www.elibrary.ru/item.asp?id=41122260 (дата обращения 01.12.2020).

12. Марчук Н.Ю. Психолого-педагогические особенности дистанционного обучения // Педагогическое образование в России. - 2013. - №4. - С. 78-85.

13. Learning English - BBC. https://learnenglish.britishcouncil.org/ (accessed December 1, 2020).

14. Learn English Online/ British Council. URL: https://learnenglish.britishcouncil.org/ (accessed December 1, 2020).

15. TED Talks. URL: https://www.ted.com/ (accessed December 1, 2020).

16. Геращенко И.Г., Геращенко Н.В. Проблемы дистанционного образования: методологический аспект // Studia Humanitatis. - 2017. - №2. [Электронный ресурс. URL: https:// cyberleninka.ru/article/n/problemy-distantsionnogo-obrazovaniya-metodologicheskiy-aspekt (дата обращения 12.02.2021).

Information about the authors

Amalia L. Kuregyan, Cand. Phil. Sci., Associate Professor of Foreign Language Department. Samara State Technical University, Samara, Russian Federation. E-mail: amleku@mail.ru ORCID: 0000-0002-0822-4274. Researcher ID: D-7928-2014

Ekaterina A. Pertsevaya, Cand. Phil. Sci., Associate Professor of Linguistics and Foreign Language Business Communication Department. Samara State Economic University, Samara, Russian Federation. E-mail: kmilyutina@mail.ru. ORCID: 0000-0002-7289-5080

Информация об авторах

Амалия Левиковна Кюрегян, кандидат филологических наук, доцент кафедры «Иностранные языки». Самарский государственный технический университет, Самара, Россия. E-mail: amleku@mail.ru ORCID: 0000-0002-0822-4274. Researcher ID: D-7928-2014

Екатерина Александровна Перцевая, кандидат филологических наук, доцент кафедры «Лингвистика и иноязычная деловая коммуникация». Самарский государственный экономический университет, Самара, Россия. E-mail: kmilyutina@mail.ru. ORCID: 0000-0002-7289-5080 